\title{
Erratum to: Atmospheric circulation and storminess derived from Royal Navy logbooks: 1685 to 1750
}

\author{
D. Wheeler • R. Garcia-Herrera • \\ C. W. Wilkinson · C. Ward
}

Published online: 17 October 2009

(C) Springer Science + Business Media B.V. 2009

\section{Erratum to: Climatic Change (2010) 101:257-280 \\ DOI 10.1007/s10584-009-9732-x}

Please note that text references to Fig. $7 \mathrm{c}$ and $7 \mathrm{~d}$ should be transposed.

The online version of the original article can be found at http://dx.doi.org10.1007/s10584-009-9732-x.

D. Wheeler $(\bowtie) \cdot C$. Ward

University of Sunderland, Sunderland, SR1 3PZ, UK

e-mail: dennis.wheeler@sunderland.ac.uk

R. Garcia-Herrera

Universidad Complutense de Madrid, Madrid, Spain

C. W. Wilkinson

University of East Anglia, Norwich, NR4 7RT, UK 